Acta Poloniae Historica

109, 2014

PL ISSN 0001-6892

Natalia Aleksiun

\title{
TOGETHER BUT APART: \\ UNIVERSITY EXPERIENCE OF JEWISH STUDENTS IN THE SECOND POLISH REPUBLIC*
}

\begin{abstract}
This paper examines the experiences of Jewish university students in Warsaw, Lvov, Wilno and Cracow, focusing on their interactions with each other as well as with other students. These experiences are divided into three categories: daily encounters and mutual relations (or the lack thereof), the vision of the academic community to which the students aspired, and Jewish students' reactions to antisemitism. I argue that for many Jewish students, these daily university experiences both on campuses and beyond strengthened their sense of being outsiders. Having been excluded from most of the general student organizations they had to form their own, which limited their interactions with other students even further, and, above all, strengthened feeling that they were being singled out and victimized.
\end{abstract}

Keywords: Second Polish Republic, Jewish students, Jewish student organizations, 'ghetto benches', Polonization.

\section{I \\ INTRODUCTION}

In 1931 Hersz Wolf Sztolcman graduated from the state gymnasium in Sochaczew and enrolled at the Department of Law at the University of Warsaw. In his autobiography, Sztolcman described the way in which his university experiences influenced his political views.

* The title of the article refers to Shimon Redlich's study of interethnic relations in the local setting of a town in Eastern Galicia. See Shimon Redlich, Together and Apart in Brzezany: Poles, Jews and Ukrainians, 1919-1945 (Bloomington, IN, 2002). In his book, Redlich presents "the multi-ethnic community of Brzeżany, where Poles, Jews, and Ukrainians lived side by side" (p. 163). He also shows the degree to which Poles, Jews, and Ukrainians for the most part experienced and remembered separate communal lives despite their shared urban space and personal interactions (pp. 34-70). His investigation of the degree and limits of interethnic integration 
When I stood with my high school diploma at the gate of life, I experienced disappointment and the golden dream that I had before graduation burst as a bubble. The brutal reality hit me hard. I understood that in social life there are powerful walls separating religions and races. Although I knew that before and there were incidents based on race in the gymnasium, but they were sporadic and I never experienced it myself because I lived very well with my colleagues. But here, in the temple of knowledge, I experienced on my own skin the hatred stemming from nationalism and chauvinism. This first spiritual struggle led me to the fork in the road with two roads to choose from: Zionism or socialism. ${ }^{1}$

Hostile encounters at the university led Sztolcman to embrace political ideologies and political activism. His account reflects the experiences of many Jewish students at Polish universities and their sense of deteriorating relations which they experienced in the classrooms and on campuses, especially in the 1930s.

Sztolcman belonged to the cohort of young citizens of the Second Polish Republic - who enrolled at state universities in Warsaw, Cracow, Wilno, Lvov and Poznań. These state universities became 'an academic commonwealth'2 bringing together men and women of diverse social, cultural, religious and political backgrounds. They sought a promise of a secure future, playing important roles as the country's elite in the offing. They met in classrooms, laboratories, libraries and corridors. Many young men and women may have entered Polish universities without a strong sense of belonging to a separate group, and without a desire to be perceived as members of such a group. For some Jewish students universities constituted a complex cultural and political encounter with their minority status. On the one hand, they became part of the state institution of higher learning, studying in Polish and surrounded by Polish colleagues and faculty, on the other hand they had to overcome many difficulties: numerus clausus

is also pertinent to the generational experience of Jewish students in the academic centers of the Second Polish Republic. I would like to thank Prof. Anna LandauCzajka, Dr. Kamil Kijek, Sara Zarrow, Izabela Mrzygłód, and Ewa Nizińska who read drafts of the article and gave me valuable feedback.

${ }^{1}$ Hersz Wolf Sztolcman, 'Prowincjał' [autobiography], in Alina Cała, Ostatnie pokolenie. Autobiografie polskiej mtodzieży żydowskiej okresu międzywojennego ze zbiorów YIVO Institute for Jewish Research w Nowym Jorku (Warsaw, 2003), 47.

${ }^{2}$ See Andrzej Pilch, Rzeczpospolita akademicka. Studenci i polityka. 1918-1933 (Cracow, 1997). 
and special language exams, as well as encountering the practice of social exclusion, especially through 'ghetto benches' (separate seats in lectures halls assigned to Jewish and Gentile students), ostracism in daily relations and physical violence. ${ }^{3}$ Their daily experiences became a transformative social experiment that changed the worldview of many students, shaping and reshaping their visions of social roles and the place or lack thereof for members of various ethnic groups.

Jewish students constituted a cohort of diverse social backgrounds and political cultures, but shared important characteristics. They belonged to what historians have described retrospectively as the generation with 'no future' or 'the last generation'. ${ }^{4}$ They were born shortly before or during WWI, came of age in the Second Polish Republic in which they were socialized and whose schools they attended. They came from all regions of Poland: Congress Poland, Galicia and the Kresy ('borderlands', formerly part of the Pale of Settlement of Imperial Russia). Universities could become a meeting place with Polish culture and the space of cultural Polonization of the Jewish youth, as it tad taken place at the turn of the nineteenth century in Lvov and Cracow. ${ }^{5}$ Jewish students enrolled at Polish universities in the 1920s and especially in the 1930s belonged to the generation that had been exposed to Polish history and literature.

${ }^{3}$ Jewish students in state gymnasia experienced many aspects of numerus clausus, social ostracism and anti-Semitism expressed openly by teachers and classmates. See Kamil Kijek, 'Między integracją a wykluczeniem. Doświadczenie szkolne jako czynnik politycznej socjalizacji młodzieży żydowskiej w Polsce okresu międzywojennego', in Aleksandra Lompart (ed.), Jednostka zakorzeniona? Wykorzeniona? Metafora $w$ socjologii (Studia i Analizy Instytutu Socjologii Uniwersytetu Warszawskiego, Warsaw, 2010), 165-97.

4 "We have already seen that the appearance of Jewish youth movements in Poland, whether Zionist or anti-Zionist, was symptomatic of the general crisis in which Polish Jewry found itself during the interwar years, a crisis which particularly affected the youth. In the 1930s, it was common to refer to the new Jewish generation as 'youth without a future', but even in the 1920s it was clear that Polish anti-Semitism and the general economic crisis in the country was endangering the economic future of young Jews", Ezra Mendelsohn, The Jews of East Central Europe Between the World Wars (Bloomington, IN, 1983), 59-60. Also see the title of the collection edited by Alina Cała, Ostatnie pokolenie, 28.

${ }^{5}$ See Natalia Aleksiun, 'Polish Jewish historians before 1918: Configuring the Liberal East European Jewish Intelligentsia', East European Jewish Affairs, xxxiv, 2 (2004), 41-54. 
With the radicalization of the political discourse in Poland and in the context of economic crisis, various aspects of exclusion increasingly shaped daily experiences of Jewish students.

In the Polish historiography, scholars had discussed universities in the 1920s and 1930s as a highly politicized space of coexistence of students who supported various political programs and who contributed to vibrant political cultures of Polish, Jewish and Slavic minorities. ${ }^{6}$ More broadly, universities were often described as a particularly dangerous space of sharp national conflicts and attacks against Jewish and Ukrainian students. Celia S. Heller described universities in the Second Polish Republic as 'the hotbed of AntiSemitism'. ${ }^{7}$ Raphael Mahler also pointed to the increasingly difficult situation of Polish Jewish students. ${ }^{8}$ More recent research tends to focus on the anti-Semitic campaigns in the 1930s. The situation at universities deteriorated in the context of the political situation in the country as nationalistic discourse became a tool in the struggle for power. ${ }^{9}$ Historians such as Szymon Rudnicki, Jolanta Żyndul, and Monika Natkowska discuss various aspects of anti-Semitic policies at Polish universities or the attitudes of students towards the so-called Jewish question, rather than the collective experience of Jewish men and women who entered Polish universities. ${ }^{10}$

${ }^{6}$ See Pilch, Rzeczpospolita akademicka.

${ }^{7}$ Celia S. Heller, On the Edge of Destruction: Jews of Poland between the Two World Wars, foreword Nathan Glazer (Detroit, 1994), 119-25.

${ }^{8}$ See Raphael Mahler, 'Jews in Public Service and the Liberal Professions in Poland, 1918-1939', Jewish Social Studies, vi, 4 (1944), 341-6; idem, Yehudey Polin Beyn Shtey Milkhamot Olam: Historya Kalkalit-Sotzyalit Leor Hastatistika (Tel Aviv, 1968), 172-5.

${ }^{9}$ See Waldemar Paruch, Od konsolidacji państwowej do konsolidacji narodowej. Mniejszości narodowe w myśli politycznej obozu pitsudczykowskiego (1926-1939) (Lublin, 1997); Eva Plach, The Clash of Moral Nations: Cultural Politics in Pitsudski's Poland, 1926-1935 (Athens, OH, 2006).

${ }^{10}$ On the difficult situation of Jewish university students in interwar Poland see: Szymon Rudnicki, 'From Numerus Clausus to Numerus Nullus', Polin, ii (1987), 246-68; Jolanta Żyndul, Zajścia antyżydowskie w Polsce w latach 1935-1937 (Warsaw, 1994), 76-82; Monika Natkowska, Numerus clausus, getto tawkowe, numerus nullus, 'paragraf aryjski'. Antysemityzm na Uniwersytecie Warszawskim 1931-1939 (Warsaw, 1999). On Polish-Jewish relations at universities see also Aleksander Srebrakowski, 'Sprawa Wacławskiego. Przyczynek do historii relacji polsko-żydowskich na Uniwersytecie Stefana Batorego w Wilnie', Przeglad Wschodni, ix, 3 (35) (2004), 575-601; Zbigniew Opacki, 'Studenci chrześcijanie wobec studentów Żydów na 
Based on diaries, academic press and university archives of student organizations, I discuss more specific questions related to the subjective experience of daily relations of Jewish students at the Polish universities during the interwar period. Did the university's physical space - classrooms, courts, corridors and dormitories - shape the contours of their national identity? What strategies emerge in their interactions with other students - both majority and minority groups? In what way did the Jewish students perceive their place in the university, when they compared their situation with that of their non-Jewish colleagues? Last but not least I would like to ask, what collective experience emerges as a primary point of reference in the discourse of Jewish identity in Poland between two world wars and beyond? ${ }^{11}$

II

\section{CHOICE OF DEPARTMENT}

In the early 1920s, Polish state universities attracted growing numbers of Jewish students as part of a rapid growth of students enrolled at various institutions of higher education. During the first decade since 1921, this number rose from 34,266 to $48,155 .{ }^{12}$ In $1939,49,987$ students were enrolled at state and private institutions of higher

Uniwersytecie Stefana Batorego w Wilnie (1919-1939)', in Wolf Moskovich (ed.), Jews, Poles and Russians: Jewish-Polish and Jewish-Russian Contacts (Jews and Slavs, 21, Jerusalem, 2008), 123-50; Agnieszka Graboń, Problematyka żydowska na tamach prasy akademickiej $w$ okresie międzywojennym (Cracow, 2008). The monographs published by Mariusz Kulczykowski provide a wealth of data but contribute less to the Alltagsgeschichte, see idem, Żydzi-studenci Uniwersytetu Jagiellonskiego $w$ dobie autonomicznej Galicji (1867-1918) (Studia nad Kształtowaniem się Inteligencji w Polsce w XIX i XX wieku, 3, Cracow, 1995); idem, Żydzi-studenci Uniwersytetu Jagiellońskiego w Drugiej Rzeczypospolitej (1918-1939) (Prace Komisji Historii i Kultury Żydów - Polska Akademia Umiejętności, 5, Cracow, 2004).

${ }^{11}$ See Alina Cała, 'The Social Consciousness of Young Jews in Interwar Poland', Polin, viii (1994), 42-66. In the student file of Chaja Mindla Czamarka, born in Warsaw in 1906, as daughter of Noach and Szejwa Brucha Grycman, we find her student documents signed as 'Helena Czamarkówna', Archiwum Uniwersytetu Warszawskiego (hereinafter: AUW), Akta Studenckie, RP, student grade book no. 13928: Czamarka Helena.

${ }^{12}$ Saul Langnas, Żydzi a studja akademickie w Polsce w latach 1921-1931. Studjum statystyczne (Lvov, 1933), 7. 
learning. ${ }^{13}$ The increase was mostly due to the number of Roman Catholic students although the number of those who declared being Greek Catholics increased as well. ${ }^{14}$ The number of Jewish students rose until 1933, but at a rate much slower than in the case of Christian students and constituted in the first decade 3.4 percent of the general rise in academic youth. ${ }^{15}$ The percentage of Jewish students varied until 1925, and then decreased sharply. During the 1921-2 academic year Jewish students constituted 24.6 percent of all those enrolled at institutions of higher learning. In the 1925-6 academic year, their percentage dropped to 20.7 percent, and continued to decrease to 18.5 percent in $1930-1$ and 8.2 percent in the last prewar academic year. ${ }^{16}$

13 Mahler, 'Jews in public service', 341.

14 Before 1925 many Ukrainians boycotted Polish institutions of higher learning, enrolling at underground institutions in Lvov instead or leaving to study abroad, especially in Czechoslovakia; Andrzej Pilch, 'Ukraińcy na wyższych uczelniach Lwowa 1923-1926', Annales Universitatis Mariae Curie-Sklodowska, section F, liv-lv (1999-2000), 239-40. In comparison with 1923 the percentage of Greek Catholic students at Polish universities rose in the 1930/1 academic year by $150 \%$; Langnas, Żydzi a studja, 10. Among Christian students the percentage of Greek Catholics rose from 0.9 in 1921 to 4.4 in 1931. In the academic year 1921/2, 237 Greek Catholic students were enrolled at Polish universities, in 1923/4 - 686, in 1925/6 - 1342, and in 1930/1 - 1539. See ibidem, 10-12, 25.

${ }^{15}$ Langnas, Żydzi a studja, 10-11.

${ }^{16}$ Ibidem, 23-4; Mahler, 'Jews in public service', 341; Gershon Bacon, 'The Missing 52 Percent: Research on Jewish Women in Interwar Poland and its Implications for Holocaust Studies', in Dalia Ofer and Lenore J. Weitzman (eds.), Women in the Holocaust (New Haven and London, 1998), 60. In the academic year 1921/2, there were 8,426 Jewish students (24.3\%); in the year 1923/4 - 9,579 (24.4\%), and in $1929 / 30-8,796(19.3 \%), 1930 / 1-8,923(18.5 \%)$. In the academic year $1935 / 6$ the percentage of Jewish students was $13.2 \%$, in $1936 / 7-11.8 \%$, in $1937 / 8$ only $10.0 \%$ and only $8.2 \%$ in 1938/1939; see Szyja Bronsztejn, Ludność żydowska $w$ Polsce $w$ okresie międzywojennym. Studium statystyczne (Wrocław et al., 1963), 192-3. In the 1930s, not only did the percentage of Jews in the student body decline, but also the absolute number of Jewish students: from $24,6 \%$ of all students in institutions of higher education in $1921 / 2(8,426$ of 34,266$)$ to only $8,2 \%$ in 1938/9 (4,113 of 49,987). Bacon, 'The Missing 52 Percent', 60. On female Jewish students in Eastern and Central European context see Carole B. Balin, 'The Call to Serve: Jewish Women Medical Students in Russia, 1872-1887', Polin, xviii (2005), 133-52; Jadwiga Suchmiel, Żydówki ze stopniem doktora wszech nauk lekarskich oraz doktora filozofii $w$ Uniwersytecie Jagiellonskim do czasów II Rzeczypospolitej (Częstochowa, 1997); Harriet Pass Freidenreich, Female, Jewish, Educated: The Lives of Central European University Women (Bloomington, IN, 2002). 
Moshe (Moszek Mendel, or Mietek) Prywes (1914-98) who graduated from the 'Chinuch' Jewish gymnasium in Warsaw in 1931 described his cohort as "the watershed generation of Warsaw Jewry". ${ }^{17}$ In contrast to the previous generation, not only did it attend gymnasia but also aspired to continue education at universities. "The real question for the Prywes clan of my day was not whether to study at university but rather which course of study and university would be most suitable." 18 Indeed, Jewish families perceived university education as an important path to ensure better future for their children. In particular, middle-class Jewish children were

thrown or threw themselves into secular studies, half-realizing that no economic benefits might follow. They pursued secular learning with something of the same deeply rooted belief of orthodox Jews in the study of sacred books, that is, that it would somehow stand them in good stead. ${ }^{19}$

The majority of Jewish students enrolled at institutions of higher learning studied at universities, especially in Lvov, Warsaw, Wilno and Cracow. ${ }^{20}$ There were 2,970 Jewish students at the University of Warsaw in the 1923-4 academic year, 2,643 at Jan Kazimierz University (UJK) in Lvov, and 1,716 at the Jagiellonian University (UJ) in Cracow. ${ }^{21}$ In 1921, Jews constituted 31.4 percent of the students at the University of Warsaw (UW), 29.6 percent at the Jagiellonian University, and as high as 46.6 percent at Jan Kazimierz University. In 1923, their percentage remained as high. ${ }^{22}$ However, in the $1930-1$ academic year that percentage at universities began to fall: to 23.8 percent in Warsaw, 26 percent in Cracow and 31.9 percent in Lvov. ${ }^{23}$ A high

${ }^{17}$ Moshe Prywes (and Haim Chertok), Prisoner of Hope, foreword Elie Wiesel (Tauber Institute Series for the Study of European Jewry, Hanover, NH, and York, 1996), 51. This drive towards university education seems hardly limited to Warsaw, see N.N. 'Kitka', in Cała, Ostatnie pokolenie, 479.

18 Prywes, Prisoner of Hope, 51.

${ }^{19}$ Haskell Nordon, The Education of a Polish Jew: A Physician's War Memoir (New York, 1982), 54.

${ }^{20}$ On Jewish students enrolled in other institutions of higher learning, see Langnas, Żydzi a studja, 11-12, 15-19.

${ }^{21}$ See ibidem, 12-13.

22 They were $46.6 \%$ at UJK, $39.5 \%$ at UJ and $31.4 \%$ at UW. See J. Ratner, 'Koła prowincjonalne', Trybuna Akademicka, i, 1 (June 1923), 18.

${ }^{23}$ The percentage at the University in Poznań decreased from 1.4\% in 1921 to $0.7 \%$ in 1930/1; see Langnas, $\dot{Z} y d z i$ a studja, 21-2. 
proportion of female Jews studied at Polish universities. ${ }^{24}$ This characteristic may be explained by the higher percentage of Jewish girls attending secondary schools in general, in turn resulting from the common practice of giving good general education to daughters while sending the sons to traditional yeshivot. ${ }^{25}$ Moreover, Jewish parents may have been reluctant to send their daughters abroad, which was a practice more common for male Jewish students.

Two departments attracted most Jewish applicants: medicine and law. Hoping to build a better future in the liberal professions, the sons and daughters of shopkeepers aspired to enroll in these departments, often with a sense that there was no future for them in their hometowns or taking over the small stores of their parents in large cities. ${ }^{26}$ Some were not drawn to liberal professions out of economic necessity. Moshe Prywes, whose father ran a successful iron business in Warsaw, dreamed of studying medicine since childhood despite an initial lack of support from his family. ${ }^{27}$ In his first application, in September 1931, Prywes declared that

I have always felt a certain draw to natural sciences, especially to anatomy. Driven by this passion and considering it my calling, I hereby apply for [admission] to the Medical School of the University of Warsaw. ${ }^{28}$

${ }^{24}$ Whereas female students made up only $23 \%$ of the general student body in 1923/4 and $27 \%$ in 1928/9, among Jewish students women comprised $33 \%$ in 1923/4 and as much as 38\% in 1928/9; see Bacon, 'The Missing 52 Percent', 60-1.

${ }^{25}$ See Shimon Frost, Schooling as a Socio-Political Expression: Jewish Education in Interwar Poland (Jerusalem, 1998), 33; Anna Landau-Czajka, Syn będzie Lech... Asymilacja Żydów w Polsce międzywojennej (Warsaw, 2006), 181-3.

${ }^{26}$ Such was the case of the Szyk family in Warsaw. Naum Szyk, born in 1898, enrolled at the Medical School of the Warsaw University in 1917; see Marcin Kula, Autoportret rodziny x. Fragment żydowskiej Warszawy lat międzywojennych (Wspomnienia, Zapiski, Diariusze, Listy, Sekrety, Pamiętniki, Warsaw, 2007), 217-18, 222.

27 "In the vast Prywes family tribe, I had never ever heard of anyone who had studied medicine. Yet, despite undeniable signs that I shared Father's business acumen, from the age of fifteen my heart was aflame with a desire to study medicine. To serve mankind as a physician, that would be my special, my singular fate among the Pryweses! I knew better than to broadcast this intention; on the contrary, fearful of it being prematurely blasted, I nursed and guarded my calling like a fragile bud." Prywes, Prisoner of Hope, 26.

${ }^{28}$ AUW, Wydział Lekarski (Medical School, hereinafter: WL), RP 422909, Moszek Prywes, Życiorys [CV], signed on Sept. 9, 1931. 
Hersz Wolf Sztolcman wrote that he decided to study law as a result of a "lemming-like rush" 29 .

Already in the 1920s, the quota system had a major influence on the situation of the Jewish students; it affected students' decisions about the choice of department and their emigration in order to study abroad. Moreover, Jewish students enrolled in departments other than medicine or law due to numerus clausus. ${ }^{30}$ Upon learning that his application to Medical School in Warsaw had been rejected, Haskel Grossman (later Haskel Nordon) enrolled in a course of higher mathematics which gave him the status of university student. ${ }^{31}$ Emanuel Ringelblum, who was not admitted to the Medical School at the University of Warsaw, decided to enroll at the Department of History and ultimately became one of the leading scholars of Polish Jewish history. ${ }^{32}$ Alternatively, a university diploma in other departments could lead to a career in education, since the Ministry of Religious Affairs and Public Education required all teachers in secondary schools to obtain university training. ${ }^{33}$

Grossman remembered being one of 500 Jewish applicants competing for only 20 places available to Jews. These tended to be filled by "sons of Jewish doctors and four or five candidates with unusual contacts or fantastic payoffs". ${ }^{34}$ He took the entry examination writing in a giant auditorium on a subject of "central heating". He wondered about the motivation of people who hoped against reason to be accepted and ascribed it to:

The subconscious belief of the Jews in miracles and the uplifting state many of us experienced by just being allowed to be candidates, even in vain; to breathe for a few hours the air of the halls of a medical school, and

${ }^{29}$ Sztolcman, 'Prowincjał', 46.

30 See 'Na początek roku akademickiego', Trybuna Akademicka, xiv, 117-18 (Aug.-Sept. 1934).

${ }^{31}$ Nordon, The Education, 83: "It was easy for Jews to be accepted into the course because no practical use could be made of it by any of us."

32 See Ringelblum's student record, AUW, RP 9070; see also Samuel D. Kassow, Who Will Write Our History? Rediscovering a Hidden Archive from the Warsaw Ghetto (London, 2009), 57-8.

${ }^{33}$ See Artur Eisenbach, 'Jewish Historiography in Interwar Poland', in Yisrael Gutman et al. (eds.), The Jews of Poland between the Two World Wars (Tauber Institute for the Study of European Jewry Series, Hanover NH, and London, 1989), 454.

${ }^{34}$ Nordon, The Education, 82-3; see AUW, RP 30136. 
the strange perverse exhilaration of satisfying one's conscience by going through the motions of doing everything possible including the utterly futile. ${ }^{35}$

Prywes described the traumatic experience of taking entrance examinations to the Medical School torn between hope and the realization that Jewish applicants for the few slots available to them included

the very cream of Poland's Jewish high school graduates. Moreover, as in many other countries, preference was unofficially accorded to the children of doctors, which meant that before I even lifted my pen to answer the first question of the exam, more than half of the twelve prize slots allotted to Jews were beyond my reach. ${ }^{36}$

Access to medical studies in Poland became increasingly difficult for Jewish students in the 1930s. Prywes spent two years studying in France at the medical school in Tours before he was accepted at the University of Warsaw in $1933 .{ }^{37}$ While some Jewish students returned from abroad when diminishing family financial resources made further study impossible and enrolled at Polish universities, others went abroad especially to study medicine. ${ }^{38}$ In his 1933 study on the Jewish students in Poland Samuel Langnas described numerus clausus as

the central issue of the academic study in Poland, which continually influences the political and social life at every opportunity and at every turn. We can easily say that no other aspect of the social life of Polish Jewry, not in the political and not in economic and not in cultural fields is until today the subject of such frequent and passionate discussion, such variety of opinions, and what's worst such shallow, worthless and even aggressive argumentations, as the matter of the participation of the Jewish youth at Polish universities. ${ }^{39}$

35 Nordon, The Education, 83.

${ }^{36}$ Prywes, Prisoner of Hope, 30; see AUW, WL, RP 422909 (Prywes's CV).

37 Prywes, Prisoner of Hope, 31.

${ }^{38}$ Haskell Grossman's older brother had to return from Grenoble where he had studied engineering because their father could no longer help him financially. He then decided to go to study law in Warsaw; see Nordon, The Education, 55; Baruch Milch, Can Heaven Be Void?, ed. Shosh Milch-Avigal (Jerusalem, 2003), 45-7.

${ }^{39}$ Langnas, Żydzi a studja akademickie, 4. 
Not only did the quota system shape the choice of departments, it also influenced the atmosphere at the universities for those Jewish students who were admitted. The calls for introducing a quota system united various student organizations. ${ }^{40}$

III

ENCOUNTERING THE CITY AND THE UNIVERSITY

Enrolling at a university exposed young Jewish men and women to new environment and new experience. The degree of change depended on the cultural background of the newly minted students. Those raised traditionally in small towns moved to Warsaw, Wilno, Cracow and Lvov, away from familial and communal supervision. They marveled at the cultural diversity, secular entertainment and academic activities. Haskell Grossman, born in 1911 and raised in a traditional Jewish family near Lodz, where his father owned a small store, described his first encounters with Warsaw:

I would sit in the library after overcoming my first bedazzlement at the sight of tens of thousands of books open to my whim. Here I could browse among the printed pages of Western civilization, could take any volume to my desk and read to my heart's content, at my own pace, and in the peace and tranquility of the light, airy, high vaulted hall. ${ }^{41}$

He also became infatuated with the sounds of a cultured metropolis: the opera and the philharmonics. Raised in an acculturated and well-to-do family in Tłuste, Ludwik Stöckel decided to study law in Lvov in order to "learn about city life" and get a taste of "student life". ${ }^{42}$ Indeed, once enrolled at the Jan Kazimierz University, he divided his time between books and journals that had been previously "inaccessible to us in the backwater province", sexual conquests, and frequenting cinema, theater and dances. ${ }^{43}$ For some, university

${ }^{40}$ In February 1925, The All-Poland Conference of Students, meeting in Wilno, passed a resolution calling on the government to introduce numerus clausus in all institutions of higher education. Heller, On the Edge, 121; see also Zofia Przybysz, 'Numerus clausus na uczelniach Drugiej Rzeczypospolitej', in Ewa Wiatr and Piotr Zawilski (eds.), Studia i szkice dedykowane Julianowi Baranowskiemu (Lodz 2010), 84-98.

${ }^{41}$ Nordon, The Education, 86.

${ }^{42}$ Ludwik Stöckel 'Lud.' [autobiography], in Cała, Ostatnie pokolenie, 369.

${ }^{43}$ Ibidem, 371. 
was a way to escape from emotionally taking conflicts with their parents at home. ${ }^{44}$

Jewish students stemmed from diverse social backgrounds, even though most had probably grown up in traditional settings, in small towns (shtetlekh) rather than urban centers. ${ }^{45}$ Arriving in Warsaw, Lvov, Cracow and Wilno, they sought living arrangements with distant relatives, or rented rooms with Jewish families. In 1935, Daniel Halpern - a law student at the Jagiellonian University - described his arrangement of being offered a room in Cracow in exchange for tutoring the family's son. ${ }^{46}$ Few were lucky enough to find accommodation at the Jewish dormitories that opened owing to the efforts of local Jewish communities in Warsaw, Cracow and Lvov. ${ }^{47}$ In 1938, a native of Sambor enrolled at the Jagiellonian University upon his graduation from the state gymnasium in Drohobycz. This student's working class family was unable to support his ambitions. He had barely sufficient funds to pay for his travel and room and board. Without any relatives or a network of acquaintances, he was able to find a place at the Jewish Academic House. ${ }^{48}$ Prywes had his own bedroom since his family business was doing well and moved into a far more luxurious apartment with three bedrooms, a large living room, dining room, and two bathrooms. ${ }^{49}$ Like many students of meager means, Grossman supported himself with tutoring. He catered to the needs of Jewish high school students in order to make ends meet. ${ }^{50}$

${ }^{44}$ See Yad Vashem, The Yiddish Scientific Institute (hereinafter: YIVO), Autobiography 3837, Kitka, p. 148084. I would like to thank Dr. Kamil Kijek for sharing this document with me.

${ }^{45}$ See Abraham Weiss and Pninah Kraemer-Weiss, 'Makhon le-mada'e ha-Yahadut be-Varshah', in Sefer ha-shanah/Yorbukh, ed. Aryeh Tartakover, ii (Tel Aviv 1967), 371.

${ }^{46}$ Dawid Halpern, 'Jeden świstek. Kartka z dziennika akademika', Trybuna Akademicka, xv, 2/3 (122-3) (Feb.-March 1935), 3-4.

${ }^{47}$ See Rafał Żebrowski, 'Budowa domu akademickiego w Warszawie i jej miejsce w dziejach warszawskiej gminy wyznaniowej', Kwartalnik Historii Żydów, 4 (216) (2005), 467-80.

${ }^{48} \mathrm{NN}$, 'Kitka', in Cała, Ostatnie pokolenie, 481-2.

${ }^{49}$ Prywes, Prisoner of Hope, 48.

${ }^{50}$ Nordon, The Education, 86. He remarked about an important aspect of this experience for his cohort at the Jewish Dormitory: "This was a source of income for students who would help Jewish students in nearby secondary schools to make better grades. This tutoring was, with some luck, more than a source of income. Sixteen-year-old girls from more prosperous families seemed to look forward to 
Another student at Warsaw University - Hirsz Gerszater - supported himself and helped his family in Wilno by giving private lessons. Moreover, he combined his university studies with the pursuit of a rabbinical degree at the Institute of Jewish Studies "which greatly limits the time in which I can work as a tutor". ${ }^{51}$ Many Jewish students came from families of meager means and unemployed parents, they struggled to support themselves through the university, working as private tutors and teachers and taking on part time positions in synagogues on holidays. ${ }^{52}$ They frequently sought to waive or postpone the payment of their tuition. In an application to the rector of the University in August 1930, Rajzla Harmelin, who enrolled at Warsaw University in 1929, requested to have her tuition fee waived:

In the previous academic year I paid the tuition very early thanks to the income I had giving private lessons. This year my financial circumstances deteriorated, I lost some of my lessons and what I am able to make barely covers my expenses. If my application is rejected, my year at the university is in jeopardy, which would be a horrible blow to me since I love the field of study that I have chosen to pursue. ${ }^{53}$

Jewish students faced formidable difficulties in pursuing their university studies. Dawid Wurm deferred his studies for two years, supporting his impoverished family in Brody. ${ }^{54}$ University files suggest that a minority among history students in Warsaw came from middle class families, whereas a significant number of the parents were teachers in primary and secondary schools. ${ }^{55}$ Students looked for employment

being tutored by young university students not only in the strict rules of Latin grammar or trigonometry"; ibidem, 86.

${ }^{51}$ AUW, RP 38708: Hirsz Gerszater, Application to the Dean of the Department, Oct. 20, 1933, Warsaw.

52 See Weiss and Kraemer-Weiss, 'Makhon', 371-2. Dora Szterenkac born in 1911 in Lodz, asked the rector to waive her tuition for the academic year 1931-2: "I support myself in the strange city giving private lessons and I am unable to pay the required tuition at the moment", AUW, RP 32060: Dora Szterenkac.

53 AUW, RP 33473: Rajzla Hermelin.

${ }^{54}$ AUW, RP 31018: Dawid Wurm, Application to the university's president, Sept. 4, 1929.

${ }^{55}$ For example, Ginda Peczenik born in 1914, who enrolled in the History Department at the Warsaw University in October 1932 and graduated in 1937, came to Warsaw from Lutsk (Euck) where her father taught at a gymnasium; see AUW, Akta studenckie II RP, student grade book no. 40835: Ginda Peczenik. 
among Jews. ${ }^{56}$ The anonymous author of an autobiography - a student at the Jagiellonian University - worked as a newspaper boy for Nowy Dziennik, cashier of a street photographer and assisted at the local elections in desperate attempts to make the ends meet. ${ }^{57}$ In 1939, he concluded:

After a year of staying in Cracow, my situation did not improve at all. I am in the same place I was at last year: without work or money, wondering around Cracow. ... I will keep on trying until the very end, if I fail, pity, I will return home and try again after a while. ${ }^{58}$

The experiences of medical students and those enrolled in other departments differed substantially. Haskel Grossman paid little attention to his classes in mathematics as he enrolled there only in lieu of being rejected by the Medical School. ${ }^{59}$ While Stöckel was able to go back home to Tłuste and return to Lvov only at the time of his exams, students enrolled in the Department of Medicine were required to be "present at every lecture and lab, students could hardly help but see a great deal of each other". 60

In addition to this important distinction, which Jewish students shared with the rest of their classmates, they believed they faced additional challenges. Members of the faculty were rarely apolitical. Students seem well aware of their professors' ideological alliances. Mosze Prywes described the ambivalent experience of having been examined by Marian Piotr Grzybowski (1895-1949), an eminent lecturer in dermatology:

As with some of the other anti-Semitic professors, it was well known that he quizzed Jewish students on the most minute, obscure details, but we accepted these conditions merely as another challenge to be overcome. As a matter of honor, all of the Jewish students in my class were determined to excel on even the most unfair examinations. After he'd finished with

${ }^{56}$ Kula, Autoportret rodziny x, 420.

${ }^{57} \mathrm{NN}$, 'Kitka', in Cała, Ostatnie pokolenie, 483.

58 Ibidem, 484.

59 "Knowing well that the subjects would not lead me nearer my goal, medicine, I started skipping classes. I would sit in the library after overcoming my first bedazzlement at the sight of tens of thousands of books to my whim", see Nordon, The Education, 85.

60 Prywes, Prisoner of Hope, 59. 
me, Grzybowski honored me with an ironic smile. "Mr. Prywes, to my great regret, I suppose I shall have to give you a very good grade." 61

Prywes commented on the courage of the few professors at the Medical School who opposed separate seating: Mieczysław Michałowicz (1876-1965), Franciszek Venulet (1878-1967), and Zygmunt Radliński (1874-1941). ${ }^{62} \mathrm{He}$ also concluded that various restrictions motivated Jewish students to perform to the best of their abilities since

because of the harassment and brutality, Jews studied all the harder. Such was the special revenge we exercised on our tormentors. To the consternation of the anti-Semites, year after year, class after class, graduation after graduation, the outstanding students in the medical school were to be found among the ranks of the bench ghetto. ${ }^{63}$

\section{IV \\ ORGANIZATIONAL LIFE}

Jewish students in the Second Polish Republic belonged to a generation with an intimate relation with Polish culture, drawn to the study of Polish literature and history. For men and women coming from provincial towns, joining student fraternities provided friendship and support networks. ${ }^{64}$ Those who were able to stay at the Jewish dormitory enjoyed its atmosphere and social and cultural activities. All in all, social and political activities were for the most part in the context of the Jewish society. ${ }^{65}$

Some departments of the Stefan Batory University (Uniwersytet Stefana Batorego, USB) in Wilno had separate organizations of Jewish students, e.g. there were the Medics' Circle (Koło Medyków) and Association of Jewish Medical Students (Stowarzyszenie Medyków Studentów Żydów Uniwersytetu Stefana Batorego), ${ }^{66}$ Academic Pharmaceutical

${ }^{61}$ Ibidem, 68.

${ }^{62}$ Ibidem, 70.

${ }^{63}$ Ibidem, 71.

${ }^{64}$ Nordon, The Education, 85.

${ }^{65}$ Ibidem, 83.

${ }^{66}$ Lietuvos Centrinis Valstybes Archivas (hereinafter: LCVA), F. 175, Ap. 15, B. 31, pp. 5-11, Statut Stowarzyszenia Medyków Żydów Uniwersytetu Stefana Batorego (The by-laws of the Association of Jewish Medical Students at Stefan Batory University). 
Association (Akademickie Towarzystwo Farmaceutyczne) 'Lechja' and Jewish Academic Caucus of Pharmacists (Żydowskie Akademickie Koto Farmaceutów), ${ }^{67}$ Association of Students of Law (Koło Prawników) and Caucus of Lawyers Jews Students at USB (Koło Prawników Żydów Studentów USB). ${ }^{68}$ There were also separate associations of students of biology and humanities while the association of Esperanto seemed to have only Jewish members. ${ }^{69}$ Initially "any Polish student of the Wilno University without distinction of sex, background and religion" could be accepted into the Academic Pharmaceutical Association of Students at USB (Akademickie Towarzystwo Farmaceutyczne Studentów USB 'Lechja'). ${ }^{70}$ During the $1929 / 30$ academic year, this association defined its membership as: "Any male or female student of pharmacy at Stefan Batory University, except for Jews", adopted by the General Council on the initiative of the Board. ${ }^{71}$ The Circle of Medical Students (Koto Medyków) underwent a similar process. In the fall 1919, the Statutes of the Medical Students stated "Any student enrolled at Stefan Batory University can be a member after submitting declaration, fee and monthly fee established at the General Assembly."72 In 1927, the General Assembly revised the by-laws adding to the formula "without distinction of sex, national origin and religion" with the phrase "except for persons of Mosaic faith". ${ }^{73}$ Adopting national definition may be traced also in the academic corporations. The by-laws of the Association 'Batorja' (Konwent 'Batorja') stated clearly that "persons of Jewish origin without distinction of religion which they

${ }^{67}$ See LCVA, F. 175, Ap.15, B. 31, pp. 70-2, Statut: Żydowskie Akademickie Koło Farmaceutów USB w Wilnie (The by-laws of the Jewish Academic Caucus of Pharmacists at Stefan Batory University in Wilno).

${ }^{68}$ LCVA, F. 175, Ap. 15, B. 31, pp. 62-5, Statut Koła Prawników Żydów Studentów USB w Wilnie (The by-laws of the Organization of Jewish Law Students at Stefan Batory University in Wilno).

${ }^{69}$ LCVA, F. 175, Ap. 15, B. 31, pp. 66-9, Statut Koła Przyrodników Studentów Żydów USB (The by-laws of the Jewish Biology Students at Stefan Batory University).

${ }^{70}$ LSVA, F. 175, Ap.I A, B. 563, p. 349v, Statut Akademickiego Towarzystwa Farmaceutycznego 'Lechja' $z$ siedzibą w Wilnie (The by-laws of the Academic Pharmaceutical Association 'Lechja' with the headquarters in Wilno). The by-laws were approved on Nov. 26, 1921.

${ }^{71}$ Ibidem p. 317; see also LCVA, F. 175, Ap. 15, B. 31, p. 73v.

${ }^{72}$ LCVA, F. 175, Ap. I A, B. 563, p. 158. The by-laws were approved on Nov. 18, 1919.

${ }^{73}$ LCVA, F. 175, Ap. I A, B. 563, p. 108v, Statut Koła Medyków Uniwersytetu Stefana Batorego w Wilnie (Wilno, 1925). 
currently practice" were excluded from membership. ${ }^{74}$ Probably in response to this change, the Association of Jewish Medical Students was organized in Wilno in the same year. ${ }^{75}$ According to the statute of that association, its members could be "any student of the Medical School at USB in Wilno of the Jewish nationality, who submitted the completed declaration to the Board." 76 Radicalization of academic circles was not limited to Polish organizations which first began to exclude Jews as a religious category and with time transformed their definition of membership to be based on nationality and race. According to the by-laws of the Jewish Academic Circle of Pharmacy Students (Żydowskie Akademickie Koto Farmaceutów) in 1926 "any pharmacy student at USB of the Jewish nationality or another nationality with no distinction for sex" could join the organization. ${ }^{77}$ Increasingly, Jewish organizations closed their ranks as well.

Changing rules of membership of student associations and study groups reflected the increasing gap diving students of various ethnic groups. Associations of minority students became subject of attacks. In Wilno, the statutes and the announcements of the Association of Jewish Medical Students were systematically destroyed. ${ }^{78}$ Did setting up separate student organizations automatically indicate tensions? The Jewish Academic Circle of Pharmacy Students thanked the medical associations for allowing the use of microscopes during the 1928/9 academic year. ${ }^{79}$ However, other reports of the same association suggest that they referenced other Jewish student organizations. ${ }^{80}$

${ }^{74}$ LCVA, F. 175, Ap. I A, B. 99 (Stowarzyszenia Akademickie), pp. 4-5v.

${ }^{75}$ See a letter to the deputy rector of the Stefan Batory University Prof. W. Dziewulski, dated June 10, 1927 and signed by the chairman and the secretary of the organization; LCVA, F. 175, Ap. I A, B. 563, p. 258r-v.

${ }^{76}$ LCVA, F. 175, Ap. I A, B. 563, p. 252v, Statut Stowarzyszenia Medyków Żydów USB w Wilnie. The document was approved by the Senate of the University on Dec. (?) 9, 1927.

${ }^{77}$ LCVA, F. 175, Ap. I A, B. 563, p. 399v.

${ }^{78}$ See Memoriał Zarząqu Stowarzyszenia Medyków Żydów USB do Rektora USB, LCVA, F. 175, Ap. I A, B. 563, p. 236r-v. The document was dated on Feb. 18, 1931. The rector and the Senate issued a warning on April 11, 1931, ibidem, p. 233.

${ }^{79}$ LCVA, F. 175, Ap. I A, B. 563, p. 384, Nov. 24, 1929.

${ }^{80}$ Several Jewish student associations were planning to organize the General Association of Jewish Study Circles at Stefan Batory University in Wilno (Ogólne Zrzeszenie Żydowskich Kót Naukowych na terenie USB $w$ Wilnie). See Report dated Jan. 23, 1933, LCVA, F. 175, Ap. I A, B. 563, pp. 368v, 369. 
Before the establishment of the 'ghetto benches' which visibly divided the student body in lecture halls, separate student organizations made social interaction between Jewish and non-Jewish students challenging. Despite religious, cultural and political differences, Jewish students who entered universities gravitated to one another, especially if they were a small minority of the incoming year. As Prywes described poignantly his own cohort:

The first day at medical school there we sat: twelve Jews including four girls, who gravitated together among the one hundred and twenty new students. Most of us had grown up in Warsaw, a few in eastern and southern Poland. Three, who had completed work towards master's degrees in order to enhance their prospects for admission to medical school, were a few years older than the rest. Every single one of us twelve was determined to rank among the very best in the class. ${ }^{81}$

The Jewish Academic House served as a meeting place for students who gathered there for lectures and political discussions: Zionists, Bundists, folkists and communists. ${ }^{82}$ Indeed, Jewish students who joined political organizations were bitterly divided. By several accounts only a minority of students remained apolitical. ${ }^{83}$ Various political factions clashed attempting to control Jewish student organizations. ${ }^{84}$ While living in the Jewish dormitory in Warsaw, Haskell Grossman considered joining a revisionist Zionist organization, Betaria. He was however critical of its excessive nationalist manifestations and the culture which he saw as exceedingly influenced by the gentile world. ${ }^{85}$ He concluded that the organization

${ }^{81}$ Prywes, Prisoner of Hope, 58.

82 Ibidem, 61; Nordon, The Education, 83.

83 Prywes, Prisoner of Hope, 59.

${ }^{84}$ In the case of the Jewish Medical Student Association at Warsaw University in the 1930s: "Every one of us greatly admired [Moshe] Kleinbaum. It was only his force of personality and general influence that prevented JMSA from turning communist in the manner of nearly all the other Warsaw Jewish student organizations of that time", ibidem, 60; see also p. 62.

85 "I watched the proceedings with fascination, listened with amazement to the Latin songs mixed with Hebrew Zionist and somewhat bawdy Polish chants and uncomfortably participated in the drinking and for me, the seemingly forced gaiety. The group was congenial but disciplined and took all of this very seriously", Nordon, The Education, 85. 
attracted students who stemmed from acculturated Jewish homes for whom the colors, swords and ritual drinking made them feel equal to their nonJewish acquaintances with whom they could not share common fraternity bonds. It was, therefore, not surprising to find an older friend of mine, from my home town, Yanek, in the fraternity. He was the son of an assimilated Jew, who except for the formal conversion, conducted his family life like a gentile and had no ties to Jewish life, language or customs. ${ }^{86}$

Jewish student organizations were also involved in political activism on behalf of Jewish students. They appealed to university authorities for a change of policies that affected the lives of Jewish students as Jews. On March 9, 1923 the Association of Jewish Academic Youth at the Jagiellonian University 'Przedświt-Ha-Szachar' asked the Senate to reject the notion of the numerus clausus. It called on the spirit of the constitution and the freedom of access to scholarship. It warned about the negative effect of numerus clausus on the youth who could not afford studying abroad and a negative impact on these who undertake such studies in terms of their 'civic education'. It also pointed to the needs of the newly reborn state for educated elites. ${ }^{87} \mathrm{It}$ further referred to the Polish cultural mission, especially among "the Slavic nations - younger in civilization terms" that required turning universities into sources of knowledge for the broad circle of students. ${ }^{88}$ A Jewish student fraternity at Warsaw University organized self-defense during anti-Semitic violence.

Armed with heavy canes, the Betaria members under the command of the burly manager of the Student House would make forays into the vicinity of the University and partake in defence brawls. ${ }^{89}$

Students sent postcards to the Ministry of Religious Affairs and Public Education appealing to have the instructions with regard to 'ghetto benches' withdrawn "in the name of justice and civic equality, respecting

${ }^{86}$ Ibidem, 84.

${ }^{87}$ Archiwum Uniwersytetu Jagiellońskiego (hereinafter: AUJ), S II, 674, Żydzi studenci na UJ 1903-1939; AUJ, S II, 672, A letter to the Academic Senate issued by the Association of the Jewish Academic Youth at the Jagiellonian University (Związek Żydowskiej Młodzieży Akademickiej UJ) 'Przedświt-Ha-Szachar', Cracow March 9, 1923, 4.

${ }^{88}$ AUJ, S II, 674, a letter to the Academic Senate, 'Świetny Senacie', 3.

${ }^{89}$ Nordon, The Education, 85. 
human and national dignity, the demands of Polish democracy and Jewish population in Poland"..$^{90}$

Commenting on the activities of separate student organizations at Warsaw University, Prywes noted:

Institutional anti-Semitism did not surprise us, however, and we quickly adapted, learning to practice whatever patience and ingenuity were needed to circumvent the hurdles erected by the system. ${ }^{91}$

Prywes commented on the experience of day-to-day anti-Semitism. He remembered the great majority of the Polish students

Never addressing the Jewish students in chance meetings, their glances expressed an incomprehensibly venomous hatred. ... Our fellow students had not the slightest fear that a display of anti-Semitism would lower their esteem in the eyes of their professors. ${ }^{92}$

Jewish students interacted together:

Given the antipathy to us, naturally we Jewish students became very closely knit. Further, far more than was common practice among our contemporaries, interaction among Jews cut vertically: we incoming Jewish students mingled freely with Jews from other years. ${ }^{93}$

\section{Moreover,}

Encountering such blatant anti-Semitism had sharply reinforced my Zionist commitment. However much I loved being back in Warsaw, breathing the air my family had breathed for at least six hundred years, the land of these Poles could never be my true spiritual homeland. ${ }^{94}$

Activities of student organizations point to the increasing marginalization of Jewish students. Aside from the separate main student associations - the Fraternal Aid (Bratnia Pomoc, also known as Bratniak) and the Jewish Students' Mutual Aid (Wzajemna Pomoc Studentów

90 See AUJ, S II, 674, a postcard signed by Zofia Nusbaumówna, a student at Jagiellonian University, student grade book no. 9028.

${ }^{91}$ Prywes, Prisoner of Hope, 59.

92 Ibidem.

${ }_{93}$ Ibidem.

${ }^{94}$ Ibidem. 
Żydów) - various departments had separate organizations for their students and separate study groups. Student associations organized libraries and reading rooms for their members, study groups, lectures, outings, excursions and dances. Thus Jewish students' interactions with their gentile colleagues were more often than not limited to the lecture halls. ${ }^{95}$ Not all student organizations advocated policies or exclusion and separation of Jewish students, but theirs was increasingly a minority voice. ${ }^{96}$

\section{$\mathrm{V}$ \\ VIOLENCE}

Jewish students at the universities in Lvov, Cracow, Warsaw and Wilno described their encounter with the unfriendly atmosphere in similar terms. It was for them a bitter experience which in many cases shaped their identity and ideological choices. ${ }^{97}$ Although they stressed in letters to the academic authorities and in the press that the atmosphere deteriorated due to the activities of a radical minority, they also warned the public that this minority was able to set the tone. The Jewish press and personal testimonies abound in accounts of violence at Polish universities, especially in the 1930s. Although perpetrated by radical right-wing students, they terrorized Jewish students as well as everybody else. In the 1930s, their attacks focused not only on male students but targeted female students as well. ${ }^{98}$

${ }^{95}$ See LCVA, F. 175, Ap. I A, B. 563, pp. 86-98, XI Sprawozdanie z działalności Zarządu Koła Medyków Uniwersytetu Stefana Batorego w Wilnie za rok 1929-30 (The 11th Report from the activities of the Board of the Association of Medical Students at Stefan Batory University in Wilno for 1929-30), Wilno, Nov. 1, 1930.

${ }^{96}$ Among the minority which voiced its protests were the Union of Polish Democratic Youth (Zwiazek Polskiej Młodzieży Demokratycznej) and the Union of Independent Socialist Youth (Zwiazek Niezależnej Młodzieży Socjalistycznej). See the Manifesto issued at the protest rally under the banner 'Fighting for Polish culture' ('Do walki o kulturę polską'), of the Union of Independent Socialist Youth on Oct. 26, 1936 in Cracow, AUJ, S II, 674.

${ }^{97}$ According to Heller "... for Jewish students in general, the fruits of their achievement were made bitter by the hate that dominated the university atmosphere", idem, On the Edge, 121.

${ }^{98}$ In Prywes' account of his experiences at Warsaw University, he described one particular incident in the anatomy building in Chocimska Street: "One day without any warning, a group of twenty burly law students - boyowka - barged 
Max Borger, a sixth-year philosophy student, complained about being assaulted when he tried to find out about anti-TB treatment. He lost his academic cap and glasses, the latter of which he was able to recover. ${ }^{99}$ Jerzy Szapiro commented on the scar from the wound to the head he sustained when attacked in the prosectorium by a gang of thugs (bojówka). ${ }^{100}$

According to one account, Jewish students of medicine had the best relations with military cadets:

Since military discipline prodded them to excel in their studies, competition for the highest grades and honors between Jews and cadets was extremely keen. In fact, because we and the cadets were nearly on a par, together we would often prepare for tests. The anomaly of studying with those we were prohibited from sitting next to during lectures was hardly lost on anyone. ${ }^{101}$

In Wilno in 1927, a rally organized by student corporations condemned two Poles, who had participated in the Jewish rallies and accused them of having betrayed their national interests. ${ }^{102}$ During the riots at the Stefan Batory University in 1931 Czesław Miłosz spoke to the right-wing students who had assembled at the university court and appealed to their humanitarian feelings. ${ }^{103}$

into the lobby. They looked toward the Endeks among the medical students. A sourfaced woman medical student named Jastrzębska pointed toward a group of us and yelled: 'Those are the kikes over there'. 'Get the Jew-bastards!' they [boyowka] yelled. The boyowka then grabbed three Jewish women students. Most of the medical students were also Endeks or their sympathizers. Nearly all of the others feared them. Perhaps not surprisingly, the most vicious of the Endeks were their young women. As the non-Jewish medical students looked on, we outmanned Jews fought a pitched battle with the boyowka. Finally they succeeded in wrestling Anna Cohen and Miriam Schneider to the high gothic windows. Screaming, clothes torn, their faces scratched, both girls were bodily thrown out the window onto the pavement below." Prywes, Prisoner of Hope, 67.

${ }_{99}$ AUJ, Do Rektoratu Uniwersytetu Jagiellońskiego w Krakowie, Nov. 20, 1937, a handwritten note.

100 Jerzy Szapiro, 'Tajne studia medycyny w getcie. Szczypta narracji. Garść refleksji', <http://lekarzepowstania.pl/tajne-studia-medyczne/tajne-studia-medycyny-w-getcie/> [Accessed April 21, 2014]

${ }^{101}$ Prywes, Prisoner of Hope, 70.

102 Protokół wiecu ogólnoakademickiego młodzieży polskiej w dniu 12 listopada 1926 r. w Auli Śniadeckich (Protocol of the general rally of Polish academic youth on Nov. 12, 1926, in Śniadeckis Auditorium), LCVA, F. 175, Ap. 1 I A, B. 171, pp. 13-19.

${ }^{103}$ Andrzej Franaszek, Mitosz. Biografia (Cracow, 2011), 124-5. 
The Jewish press protested against violence at universities. On the pages of the Polish-language Jewish daily in Cracow, journalist Wilhelm Berkelhamer asked rhetorically "Is it in the best interest of the Polish state to beat and abuse Jewish youth at Polish universities - not only physically but even more morally?" He argued that beating Jewish students would not solve the problem of the perceived Jewish surplus but harm the Polish spirit instead as those attacked belonged to a weak and outnumbered minority. ${ }^{104}$ On the pages of Jewish press, Jewish communal leaders condemned violence at universities and criticized academic authorities for not taking serious enough measures in trying to stop it. ${ }^{105}$ Berkelhamer wrote ironically of a certain tradition almost sacred of annual violence at all universities at the beginning of the academic year. ${ }^{106}$ Academic authorities attempted to prevent this kind of violence. The rector of the Jagiellonian University requested that the Dean of the Medical School keep the students of the first year busy so that they would not engage in incidents with other students. ${ }^{107}$ Following disturbances in classrooms university authorities closed down certain departments, frequently medicine and law. ${ }^{108}$

Violence constituted a tangible part of the experience of Jewish students and could present real difficulties for completing the degree. In April 1937, history student at Warsaw University Abram Gawurin applied to the rector for relief from additional fees. He argued that he was injured at the University court on February 28 and as a result he was hospitalized and lost his private lessons - which were the source of his only income. ${ }^{109}$ For some students the encounter with hostility at universities led to a decision to quit studies altogether. This was the case of a student at the Jagiellonian University who had been attacked on the first evening after his arrival in the

${ }^{104}$ Wilhelm Berkelhammer, 'Mowa o ekscesach', Nowy Dziennik, 21 Nov. 1932, p. 2.

${ }^{105}$ See Ozjasz Thon, 'Tragiczny dylemat', ibidem, 19 Nov. 1932, p. 2.

106 Berkelhammer, 'Mowa o ekscesach', 2.

107 AUJ, S II, 674, Rektor UJ do Pana Dziekana Wydziału Lekarskiego, Cracow, Nov. 24, 1936.

${ }^{108}$ See the unsigned report AUJ, S II, 674, 'Przebieg zajść na Uniwersytecie Jagiellońskim w listopadzie 1936 r.' [The course of incidents at the Jagiellonian University in November 1936].

${ }^{109}$ AUW, RP 43330, handwritten letter dated April 9, 1937. 
city. ${ }^{110}$ In her postwar testimony Czesława Erlich, who had graduated from a gymnasium in Siedlce in 1930 and enrolled at the Department of Humanities at Warsaw University, described such a decision as follows:

After two years I decided to give up further study because of the lack of perspectives for the future. But the decisive reason for my quitting was antiSemitic incidents at the university. One November day in 1932, I witnessed how a group of brattish students fell on Prof. Bałaban as he was leaving the lecture hall. I stood motionless with my eyes fixed on the professor's hat which fell on the ground by my feet and became in my eyes a symbol of our humiliation. ${ }^{111}$

She decided to leave the university and enroll at the nursing school instead. One student of law complained of his inability to leave abroad to study in a less oppressive atmosphere in France, Belgium or Palestine. ${ }^{112}$

\section{VI \\ 'GHETTO BENCHES'}

In October 1937 representatives of the student organizations and academic corporations at Jagiellonian University sent a letter to its rector Władysław Szafer requesting assigning separate seats for Jewish students. They motivated their request by referring to the ambitious program of national rebirth framed as building Poland as a country without Jews:

Polish Academic Youth at the Jagiellonian University with deep concern for the future of its Nation, see the removing of the foreign Jewish element from the Polish social life one of the necessary conditions for this future.

${ }^{110}$ A Jewish student newly accepted at the University of Cracow described in his autobiography his first evening in the city. Upon his arrival, he had ventured on a walk in town and was beaten up by an Endek group: "I was so disgusted, that I felt like returning home without unpacking ... . For a long time I felt horrible. I was scared. It seemed as if everybody out there was waiting to attack me", YIVO, Autobiography 3837, cited in Heller, On the Edge, 124; see the same fragment in the Polish original, N.N. 'Kitka', in Cała, Ostatnie pokolenie, 483.

${ }^{111}$ Yad Vashem Archives (YVA), Testimonies O.3, f. 1589, 1.

112 A Jewish law student wrote after his graduation: "I was sick over having to study in Poland. I envied the people who managed to study in France, Belgium, or Palestine. If I had only been able to go abroad. But I did not have the resources"; YIVO Autobiography 3722, as cited in Heller, On the Edge, 121. 
Before a complete removal of the Jewish population from Poland is possible, [the youth] wishes to move this issue further in its own place. ${ }^{113}$

Students went on to explain that "direct contact with Jewish students leads to spreading communism, lowers morality and breeds national indifference, is inappropriate and leads to many conflicts and disturbances of peace at the University ...."114 After several weeks, the rector who initially appealed to the students to calm down, and to the ethos of academic community, gave in and agreed to assign separate seats for the students. Several Ukrainian students declared their signatures not valid as they did not want to participate in the Polish-Jewish conflict. In a letter to the rectors of the Jagiellonian University Włodzimierz Konrad stated: "I am of Ukrainian nationality and I do not want to engage on either side in the internal incidents of the Polish youth." 115 The establishment of the 'ghetto benches' culminated a process of segregation and marginalization of Jewish students. It affected all students who were assigned Jewish identity regardless of their actual sense of ethnic affiliation. ${ }^{116}$

Jewish medical students stood in protest, while taking notes on the shoulders of the students standing in front. ${ }^{117}$ In response to 'ghetto benches' Jewish students wrote to academic authorities. In 1937, Wanda Abramowicz explained "I cannot treat the seat assigned to me as a 'asylum'. All students have the opportunity to choose their seat freely in the classroom and I am not allowed to do so under the threat of disciplinary retribution." She insisted that she had no incidents with her colleagues in the past and that she never provoked any. ${ }^{118}$

'Ghetto benches' caused Jewish students of various political camps to unite, and brought to the fore those who had wished to remain apolitical as it

113 AUJ, S II, 674, Petycja polskiej młodzieży akademickiej U.J. w Krakowie (A petition of the Polish academic youth at the Jagiellonian University in Cracow).

114 Ibidem.

115 AUJ, S II, 674, a handwritten letter dated Nov. 18, 1937.

116 See the comments noted by Antoni Słonimski who described separate seating for Jews and Poles as a "serious injustice for those students of Jewish origin who feel deeply Polish”, idem, Kroniki tygodniowe, iii: 1936-1939 (Warsaw, 2005), note no. 1, Jan. 5, 1936.

117 Prywes, Prisoner of Hope, 69-70.

118 AUJ, S II, 674, handwritten letter sent by Wanda Abramowicz - a fifth year medical student, dated Cracow, Nov. 23, 1937. 
made it impossible for even apolitical Jewish students to keep aloof from larger Jewish concerns. An almost immediate result of the bench ghetto rule was the promotion of solidarity among the normally disputatious lot of Zionist, folkist, Bundist, communist, socialist, and assimilationist Jewish students. ${ }^{119}$

Prywes convened an emergency meeting of the Association of Jewish Medical Students at Warsaw University (Żydowskie Stowarzyszenie Medyków UW):

almost everyone came. Astonishingly, there was a unanimous agreement that this new, blatant, discrimination was of a new order of magnitude and called for a creative response. Although we knew we were powerless to reverse the regulation, we felt obliged not to submit. ${ }^{120}$

There were Polish students who protested 'ghetto benches'. Prywes remembered a left-wing student Tadeusz Zakrzewski who demonstratively sat with Jewish students. Zakrzewski was "followed by two Ukrainian students, less because they sympathized with Jews than because they too were a small exposed minority." Prywes singled out three outstanding students who "made a special point of speaking to me in a friendly fashion”: Tadeusz Koszarowski (1915-2002), Tadeusz Orłowski (1917-2008), and Lucjan Stępień (1912-1986). ${ }^{121}$ In the fall of 1936 when violence broke out at several departments of the Medical School at the Jagiellonian University, a Polish student who defended Jews was harassed. ${ }^{122}$

'Ghetto benches' became a symbol of the isolation of Jewish students at Polish universities when they were forced to take seats assigned to them in lecture halls. Many wrote letters to the Ministry of Religious Affairs and Public Education and to the academic authorities. Some chose to stand in protest. Klara Mincberg - the daughter of the head of Tarbut school in Rzeszów remembered standing by the wall for four years of her study at Warsaw

119 Prywes, Prisoner of Hope, 69.

120 Ibidem.

121 Ibidem.

122 The incident occurred on Nov. 18, 1936 when Jews were forcibly removed from the classrooms of the Departments of Normal and Pathological Anatomy, Dermatology and Pediatrics. See the unsigned report titled 'Przebieg zajść', AUJ, S II, 674 . 
University. ${ }^{123}$ Another student who began attending Warsaw University in 1936, was not allowed to take his exams in his third year:

I was at the time a chairman of anti-ghetto committee and Professor Rybarski refused to give us the necessary signatures because we did not take seats in the benches assigned to us. For this reason we were unable to take exams. Professor Rybarski was a well-known Endek and therefore his position did not surprise us. ${ }^{124}$

Representatives of Jewish students appealed directly to the Minister of Education asking for issuing directives that would safeguard Jewish students' freedom and safety. ${ }^{125}$ Students sent postcards appealing to the Minister of Education "in the name of justice and civic equality, respect of human and national dignity" to take back the directives of the 'ghetto benches'. ${ }^{126}$

Jewish students at the Jagiellonian University turned to the Senate appealing for it to take a stand against numerus clausus. They argued against the claim that Jewish students enjoyed a privileged position due to their alleged good economic situation and warned that the quota system would harm Poland morally in the international arena. ${ }^{127}$ The 'Days without Jews' (Dni bez Żydów), which became 'Week without Jews', although announced by the most radical groups of students, affected the atmosphere of daily contacts. ${ }^{128}$

${ }^{123}$ Klara Maayan (Mincberg), 'Bein Hashanim 1924-1939', in Kehilat Raysha - Sefer Zikaron (Tel Aviv, 1967), 183-5, here: 185; see also Mundek Hebenstreit, 'Yehudim vePolanim beYaroslav vehayechasim beineihem bishnot 1918-1945', in Sefer Jaroslaw (Tel Aviv, 1978), 205-14, here: 207.

124 YVA, Testimonies O3, 1644, Dr. Gustaw-Szmuel Auscaler, 8. He was born in Warsaw, May 31, 1917. He graduated from Mikołaj Rej Gymnasium and enrolled at the Warsaw University to study law, ibidem, 5.

125 AUJ, S II, 674, Ministerswo Wyznań Religijnych i Oświecenia Publicznego, Warsaw, Dec. 16, 1936, IV M-13752/36.

${ }^{126}$ AUJ, S II, 674, A postcard signed by Zofia Nusbaumówna, a student at the Jagiellonian University, student grade book no. 9028.

127 AUJ, S II, 672, A letter to the Academic Senate issued by the Association of the Jewish Academic Youth at the Jagiellonian University 'Przedświt-Ha-Szachar', Cracow, March 9, 1923, pp. 1-5.

128 See 'Z frontu akademickiego - dzień bez Żydów, Uniwersytet J. Piłsudskiego', Nasz Przeglą, 27 Nov. 1938, p. 10; 'Po zawieszeniu zajęć na Uniwersytecie', ibidem, 2 Dec. 1938, p. 10. 


\section{VII \\ JEWISH ENCOUNTERS WITH UKRAINIAN STUDENTS}

In the Second Polish Republic, Jewish university students seemed to have been mostly concerned with their encounters with their Polish colleagues. They did not consider Ukrainian students as potential allies in the struggle for improving the situation of minority students at universities in Lvov, Cracow and Warsaw. Archival research suggests complex relations, although representatives of the Jewish student organizations in Lvov wrote in support of creating Ukrainian academic institutions. Individual students expressed their sympathy for the difficult situation of the Ukrainian minority. ${ }^{129}$ In most accounts however, Ukrainian students were not mentioned while the main danger came from the Polish majority. Ludwik Stöckel, born to a Polonized family of Jewish landowners, described in his memoir his experiences in Lvov, where he studied law. He mentioned encounters with Polish anti-Semites but noted nothing about Ukrainians. ${ }^{130}$ Jewish autobiographies, diaries and memoirs suggest a sense of social distance vis-a-vis Ukrainians. Jewish personal accounts rarely discuss the subject of anti-Semitism or the political visions of the Organization of Ukrainian Nationalists (Orhanizatsiya Ukrayins'kykh Natsionalistiv, OUN). Anti-Semitism was a problem discussed only in relations with the Polish majority. On the other hand, Ada Birecka-Jaworska reminisced about her Ukrainian colleagues at the Medical School in Lvov, who accompanied her and defended her from anti-Semitic attacks. ${ }^{131}$ Student pres touched on challenges common to the studying youth: economic difficulties, high fees, shortage of scholarships and dormitories, scholarships and dormitories, as well as anxiety about prospects of employment upon graduation. Even in the context of open conflict, there were students who defended their Jewish colleagues and their

129 See 'Sprawa uniwersytetu ukraińskiego Lwów 21 lutego', Chwila, 23 Feb. 1924, p. 5; 'Uniwersytet ukraiński', ibidem (14 Nov. 1924), 1; see also Milch, Can Heaven Be Void?

130 See Ludwik Stöckel 'Lud.', in Cała, Ostatnie pokolenie, 336-7. His family of Polonized Jewish landowners expressed a negative attitude to the Ukrainian soldiers.

${ }^{131}$ USC Shoah Foundation, interview with Ada Birecka-Jaworska, code 16666. 
rights. For organizations of Ukrainian students the Jewish presence at universities was not central to their political agenda. ${ }^{132}$

\section{VIII \\ CONCLUSIONS}

The experiences of youths attending universities in the Second Polish Republic depended to a large extent on their ethnicity - whether freely ascribed to or imposed upon them. Although many Jewish students coming from the borderlands or from Yiddish-speaking families had positive experiences, in reality the university was more a place of marginalization than it was a place of integration. The atmosphere at the universities was largely dependent on the Polish students, who constituted the privileged majority. Many of them perceived the visible presence of Jewish students as a challenge or a threat. Thus, Jewish students in Warsaw, Lvov, Cracow and Wilno built a particularly complex relationship with their Polish and Ukrainian colleagues. For the bulk of Jewish students, attending university 'together' with other non-Jews meant exercising the right to enroll and study at Polish universities while maintaining their own cultural, religious, and national identity. In the context of these conflicting visions, Polish universities increasingly became a contested space in which Jewish students were singled out for segregation and marginalization.

132 See Maksym Gon, Iz kryvdoyu na samoti. Ukrayïns'ko-evrě̌s'ki vzaemyny na zakhidnoukraïns'kykh zemlyakh u skladi Pol'shchi (1935-1939) (Rivne, 2005). 